\title{
ECO-FRIENDLY ACCOMMODATION FACILITIES IN MLADÁ BOLESLAV, CZECHIA: A CASE STUDY
}

\author{
Petr Scholza (iD, Lenka Červováb (iD) \\ a Technical University of Liberec, Faculty of Economics, Department of Marketing and Trade; https://orcid.org/0000-0002-2637-7119; \\ e-mail: petr.scholz@tul.cz \\ b Technical University of Liberec, Faculty of Economics, Department of Marketing and Trade; https://orcid.org/0000-0001-7025-7045; \\ e-mail: lenka.cervova@tul.cz
}

How to cite (APA style): Scholz, P., Červová, L. (2021). Eco-friendly accommodation facilities in Mladá Boleslav, Czechia: A case study. Turyzm/Tourism, 31 (2), 103-116. https://doi.org/10.18778/0867-5856.31.2.06

\begin{abstract}
The purpose of this article is to evaluate the application of various green management measures in selected accommodation facilities in Czechia, namely in the town of Mladá Boleslav and its surroundings. This study was carried out using mixed research methods including semi-structured interviews with accommodation facility management staff. The interviews were complemented with a questionnaire survey which focused on the application of eco-friendly solutions in accommodation facilities. The total sample of participating facilities represented $39.6 \%$ of those in the town and its surroundings. In the data analysis stage, correspondence analysis was used. The results suggest that the higher the category, the stronger the trend to use eco-friendly methods in running accommodation facilities.
\end{abstract}

\section{KEYWORDS}

green elements and measures, environment, accommodation facility, Czechia

\section{ARTICLE INFORMATION DETAILS}

Received:

14 October 2021

Accepted:

8 November 2021

Published:

21 December 2021

\section{INTRODUCTION}

Planet Earth's environment has been undergoing enormous changes over recent decades, far greater than ever before. Environmental responsibility has increased as the current health crisis has become more critical; the real traces caused by humanity when its usual activity is interrupted (Soria, Parra, 2021). The COVID-19 pandemic is affecting not only tourism, but also other areas of business. There is a demand for modern and effective methods for increasing profitability and cost-effectiveness, significant because revenues from tourism have dropped worldwide by $74 \%$. There is noticeable pressure on cost reduction throughout society at this time. According to Sangeetha
\& Rebecca (2020), the green approach can, over the long term, reduce business-operating costs while increasing the value added to society. Tourism represents 10\% of global GDP and is responsible for $5 \%$ of global $\mathrm{CO}_{2}$ emissions, of which $1 \%$ is attributed to accommodation facilities (Khatter, Whyte, Pyke, McGrath, 2021). The Earth's energy resources are not infinite; therefore, resource conservation should become an important component of the green management of each facility (Tiwari, Dambhare, Tripathi, 2020). However Sadom, Quoquab and Mohammad (2021) point out that the problem of overconsumption in the accommodation industry is caused mainly by the irresponsible consumer behaviour of accommodation guests. Eco-friendly products and services have seen a great deal of success 
in response to the increased sensitivity of guests caused by concerns over the current state of the environment (Gupta, Satyabhusan, Mishra, 2019). Gil-Soto, ArmasCruz, Morini-Marrero and Ramos-Henríquez, (2019) suggest that eco-friendly advertising is currently widespread in the accommodation industry and it is a known fact that it supports sustainable behaviour and eco-friendly consumption. In their research, Moise GilSaura and Molina (2021) emphasize that it is important for accommodation facilities in developing countries to implement green measures in order to improve their image and increase the level of trust and satisfaction on the part of their guests, while maintaining long-term relationships and gaining prospective clients.

\section{LITERATURE REVIEW}

Environmental protection is currently a burning issue that draws a lot of attention and is discussed in all areas of life (Graci, Dodds, 2008; Petkova, 2017; Trejos, 2013). The effort to minimize any negative effects on the environment is also manifested in the accommodation industry in the form of environmental management. The hotel industry is increasingly taking responsibility for the sustainable development of the natural environment and this remains the primary objective. Accommodation facilities should focus more on energy and water consumption, as waste production is directly related to the financial benefits associated with efficient operation (Kapera, 2018). It has to be said that the majority of accommodation facilities are beginning to be environmentally conscious and are aware that apartments and boarding houses should be more engaged in sustainable practices, and thus contribute to improving the environment at both local and national levels (Tran, 2009). The construction of new accommodation facilities results in the reduction of living space for local fauna and flora, therefore it is important to take an environmental approach to mitigate the negative impacts (Kalábová, Abrhám, 2016). The future of the hospitality industry is built upon green and socially responsible principles (Tran, 2009). A well-preserved environment seems to be the best option to ensure positive feelings for all stakeholders, particularly guests which is why it is important to make sure that running a business involves eco-friendly processes and thus contributes to a better result for this entire branch of the economy without posing a threat to profitability or financial reliability (Dani, Tiwari, Negi, 2021). Environmental management (also known as green management) refers to a philosophy, technology and methodology for an organization aimed at optimizing the effect of its operation on the environment. Its principal goals are the economical use of materials, energy and other resources, and the reduction of factors posing a burden on the environment. Finally, yet importantly, one of the advantages is competitive differentiation. To run eco-friendly accommodation does not require relevant certification and a large initial investment. In their study, Sangeetha \& Rebecca (2020) verified that over the long-term, accommodation applying eco-sustainable principles reduces costs and improves the rate of return on investment. Omune, Kambona, Wadongo and Wekesa (2021) note that the government should provide a financial support for accommodation when implementing costly environmental measures.

It is necessary to state that there is no uniform definition regarding eco-friendly accommodation facilities. A guest could choose between two types of facilities that focus on the application of green management steps. The first type is those facilities that have been able to meet the demanding criteria for environmental certification and have subsequently obtained it. The second group consists of environmentally active and friendly buildings that apply countless elements of green management, but do not have an environmental certificate due to financial issues. This means that accommodation does not necessarily have to be certified in order to become environmentally active and help to improve the quality of its surroundings. This is the authors understanding regarding eco-friendly accommodation facilities. On the other hand, the Green Accommodation Association defines 'green accommodation' as that which operates in an 'environmentally friendly' way (Green Accommodation Association, 2015). Through these activities, it can increase guests' awareness of green management and thus generally increase the demand for environmental elements. Hou and Wu (2021) state that one of the most important reasons for an eco-dimension is guest satisfaction. In part, we do not agree with this statement because there are only five such facilities in Czechia representing only $0.053 \%$ of the 9,383 accommodation facilities. Guests orient primarily by price, not by green measures. The practice of using 'green' or 'eco-friendly' as a marketing ploy is still widespread in many cities and towns around the world. Many accommodation managers are claiming that they are 'environmentally friendly' by simply hanging a sign and declaring themselves to be green (Pizam, 2009).

A number of environmental measures are aimed at reducing the consumption of energy (Wan, Chan, Huang, 2017), water (Gössling, Hall, Scott, 2015; Reddy, Wilkes, 2015), chemicals, office supplies, waste, while increasing the share of natural materials, environmental aesthetics, alongside reducing noise and other emissions (Chen, Hsieh, 2011). Accommodation facilities proceed differently in choosing cost-saving measures. Some make their decision based on what is currently most urgent; others choose measures 
that deliver the largest savings at the lowest costs. Environmental responsibility takes on many different forms, including energy management and recycling procedures, switching off lights, monitoring the use of air-conditioning units and waste recycling (Bansal, Roth, 2000).

In the procurement of raw materials and products, accommodation facilities should prefer regional products and specialties, try to support the local infrastructure, ensure continual training of their staff regarding the use of new technologies, and keep to the principles of environmental management. In a friendly fashion, they should also raise their guests' environmental awareness. In addition, it is necessary to sort waste and reuse recycled materials. Waste management can help reduce the volume of generated, conserve raw materials and natural resources, energy while making financial savings. The basic prerequisite for waste reduction and its efficient use is sorting based on the type of material into metal, paper, glass, plastic, bio-waste and used oil (Patúš, Gúčik, 2005). Despite numerous environmental practices, for example, in housekeeping, some measures do not necessarily make as big a difference as expected, but certain practices may present an excessive burden on housekeeping staff (Choy, Cheng, Yu, 2021). As the prevention or reduction of food waste is one of the priorities in the process of waste reduction, specific recommendations should be made in the accommodation and hospitality industries. The European Commission states that around 88 million tonnes of food worth EUR 143 billion are estimated to be thrown away annually. Restaurants in Europe generate approximately $12 \%$ of the total amount of food wasted, producing over 10 million tonnes of food waste annually. This is more than EUR 17 billion worth of food per year (Ratinger et al., 2020). Food supply management should meet suitable food storage conditions and consumption changes should be monitored. It is recommended that facilities keep records of the volume and types of food waste generated (Priefer, Jörissen, Bräutigam, 2016) Meal portions should also be held in check. Catering facilities should process foodstuffs based on food standards, efficiently and without waste. Portion sizes need to be reduced, especially for what makes up the largest part of food waste. This is confirmed, for example, in a study focused on food waste in buffet-type catering. The study proved that more food was wasted at dinner buffets than at breakfast buffets, with more food left uneaten on customers' plates at dinner (Juvan, Grün, Zabukovec Baruca, Dolnica, 2021). Last but not least, facilities should also raise guests' awareness of the negative effects of wasting food (Betz, Buchli, Göbel, Müller, 2015; Engstrom, Carlsson-Kanyama, 2004; Pirani, Arafat, 2016). Some accommodation facilities and restaurants encourage guests to take their uneaten food home to be consumed later (Zuraikat, Roe, Smethers,
Rolls, 2018). Processes should also be put in place to ensure the rational use of leftovers to minimize waste production, i.e., prepare and sort them for staff, donate soup and other types of food to institutions and so on (Awasthi et al., 2018).

\section{DATA AND METHODS}

The goal of this article is to analyse the application of green measures in selected accommodation facilities in Czechia in the town of Mladá Boleslav and its surroundings. In connection with the research goal, the following research question was posed: What environmental management measures are most often applied in the accommodation facilities selected? For this article, primary data collected by qualitative semistructured interviews with members of management and a questionnaire survey were used. The interviews were conducted in the town of Mladá Boleslav and its surroundings $(n=19)$ between June and December 2020. The total sample of participating facilities represented $39.6 \%$ of those in this town and its surroundings. Additional information was acquired through a questionnaire survey by email or telephone. The questionnaire consisted of twelve questions: the first five were of a general nature and served the purpose of identifying the respondent, i.e., the accommodation facility into appropriate categories (Tiwari, Dambhare, Tripathi, 2020; Yoon, Sauri, Rico, 2021) while others focused on the usage of green management. One of the most significant questions was whether the particular facility had a green management concept in place at all (Rawashdeh, Al-Ababneh, 2021; Tourkolias, Kontogianni, Damigos, Skourtos, 2020). Another section dealt with individual green management measures and elements (Moise, Gil-Saura, Molina, 2021; Sangeetha \& Rebecca, 2020; Švec et al., 2021). The questions were formulated in such a way that respondents could choose from several options. The questionnaire also inquired whether accommodation facilities found the implementation of green management an advantage and whether they will strive to gain a green management certificate. Finally, it posed questions about the different ways in which guests are informed about an accommodation facility's green activities. All the participants remained informed concerning the research and the privacy of the questionnaire and all of them were willing to participate.

For the evaluation, we used an analytical method (so-called Correspondence analysis - CA). Using the graphic tools of CA, it is possible to describe an association of nominal or ordinal variables and to obtain a graphic representation of a relationship in multidimensional space, which is easier to understand. 
The analysis provides further evidence that there are dependencies between variables.

Correspondence analysis (CA) is a multivariate statistical technique. It is conceptually similar to principal component analysis but applies to categorical rather than continuous data. In a similar manner to principal component analysis, it provides a means of displaying or summarizing a set of data in twodimensional graphical form (Zámkova, Prokop, 2014). All data should be non-negative and on the same scale for CA to be applicable. This method treats rows and columns equivalently. It is traditionally applied to contingency tables - CA decomposes the chi-squared statistic associated with this table into orthogonal factors. The distance between single points is defined as a chi-squared distance. The distance between the $i$-th and $i^{\prime}$-th row is given by the formula:

$$
D\left(i, i^{\prime}\right)=\sqrt{\sum_{j=1}^{c} \frac{\left(r_{i j}{ }^{\prime} r^{\prime}{ }^{\prime}\right)^{2}}{c_{j}}}
$$

where $r_{i j}$ are the elements of row profiles matrix $R$ and weights $\mathrm{C}_{\mathrm{i}}$ correspond to the elements of column loadings vector cT, which is equal to the mean column profile (centroid) of the column profiles in multidimensional space. The distance between columns $j$ and $j$ ' is defined similarly, weights correspond to the elements of the row loadings vector $\mathrm{r}$ and sum over all rows. In correspondence analysis, we observe the relation between single categories of two categorical variables The result of this analysis is a correspondence map introducing the axes of the reduced coordinates system, where single categories of both variables are displayed in graphic form. The aim of this analysis is to reduce the multidimensional space of row and column profiles and to save as much as possible original data information. Each row and column of the correspondence table can be displayed in c-dimensional (r-dimensional respectively) space with coordinates equal to the values of the corresponding profiles. The row and column coordinates on each axis are scaled to have inertias equal to the principal inertia along that axis: these are the principal row and column coordinates (Hebák et al., 2007).

\section{RESULTS AND DISCUSSION}

A total of 19 accommodation facilities participated in the survey. Almost three-quarters were hotels (73.7\%), followed by apartments $(15.8 \%)$ and guest houses $(10.5 \%)$. In terms of hotels, the most common class was Standard (52.6\%), along with First (15.8\%), Luxury
(10.5\%), and Economy (10.5\%). Tourist class was not included in the research. We also have to state that two were not classified in any class, as this is not an obligation under Czech legislation (apartment and guesthouse). We are aware that the numbers of different types of accommodation are not the same, but they reflect the situation in Mladá Boleslav and its surroundings. More than half (52.6\%) had between 21-50 rooms, another $42.1 \%$ had between 5-20 rooms, and less than one tenth $(5.3 \%)$ had a capacity between 51-100 rooms. Hotels with more than 100 rooms did not take part in this research. More than half $(57.9 \%)$ did not have a green management concept, almost onethird (31.6\%) had one while the remaining $10.5 \%$ did not know whether they had a concept or not. However, this does not mean that they did not apply some elements of green management.

Over three quarters of the accommodation surveyed $(84.2 \%)$ chose to separate their waste. This may seem a high figure, however it must be stated that every facility is legally obliged to separate waste even if it does not strive for a green certificate, and it is the least costly way to start helping the environment. Over one half $(57.9 \%)$ have reduced their water and electricity consumption and almost half (42.1\%) were trying to reduce chemical consumption. More than a quarter $(26.3 \%)$ had made efforts to educate and communicate with their staff and guests. All of the interviewed facilities had implemented at least one element of green management (Figure 1). We believe that the surveyed facilities could clearly work on better communication with employees and guests about green issues. The most commonly used measure was energy-saving light bulbs $(89.5 \%)$ which save a significant amount of energy and are one of the cheaper options to start being a green accommodation facility. For example, a medium-sized facility with approx. 200 lights can

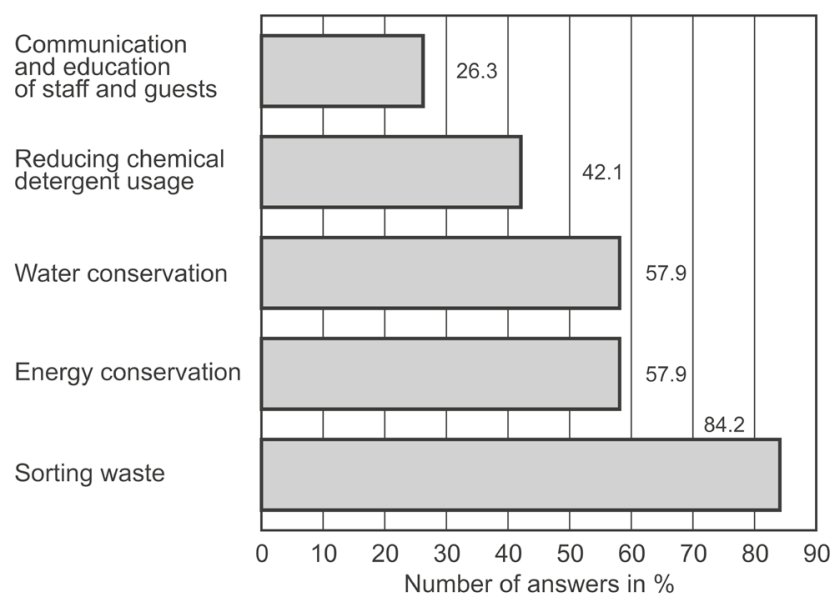

Figure 1. The application of environmental management principles Source: authors 
achieve savings of over CZK 1.1 million because of their complete replacement.

The second measure, which was selected by a significant number of facilities, was the regulation of heating in each room and with it a change of bed linen and towels only on request $(79 \%)$. The heating regulation shows the importance of saving electricity. If a room is not being used by a guest but is only ready, it is unnecessary to use air-conditioning or heating. It is sufficient to turn on the air-conditioning or heating several hours before the guest's arrival. The use of sorting containers was chosen by $73.7 \%$ of facilities. More than half (57.9\%) applied a measure to prevent unnecessary water flow, namely a twostage flushing system in toilets, which allow users to choose between flushing with three or six litres of water. Oddly enough, only $36.8 \%$ of the facilities used pearl taps, water-saving taps, or water-saving showerheads. A water-saving tap can reduce water usage by about $70 \%$ in bathroom sinks without reducing user comfort. As for water-saving showerheads, the results of reducing water consumption are not as precise as in water-saving taps. Compared to classic showerheads, a water-saving one can reduce water consumption by up to $40 \%$, i.e. to a flow rate of $12-15$ litres per minute. Just like the replacement of light fixtures, the cost of these devices is not high. A water-saving tap and a water-saving showerhead cost approximately CZK 500.

Almost half (47.4\%) used thermally insulated windows which retain heat in a room in winter, while the required temperature is maintained by airconditioning. Only $36.8 \%$ applied green management education to their employees. This measure means, for example, various training sessions on green management, or communication between managers and employees; i.e. sorting waste, turning off lights, not leaving air conditioning or heating on unnecessarily, etc. Almost one-third did not use disposable packaging for butter, jams, shampoos, etc. The removal of such packaging is one of the essential steps in green management, avoiding wasteful use of plastic and avoiding unnecessary waste sorting and subsequent recycling. The problem is that over $90 \%$ of the negative impacts associated with the production, consumption and disposal of plastics are not included in their market price. Another item is the cost of waste management, paid for through taxes and charges. The most significant quantified item is the remediation of the damage caused by plastics to the environment, including the oceans, as well as lost revenues from fisheries and especially tourism due to marine pollution. More than a quarter of accommodation facilities $(26.3 \%)$ separated bio-waste. The use of recycled paper and of central switches in rooms or the use of motion sensors obtained

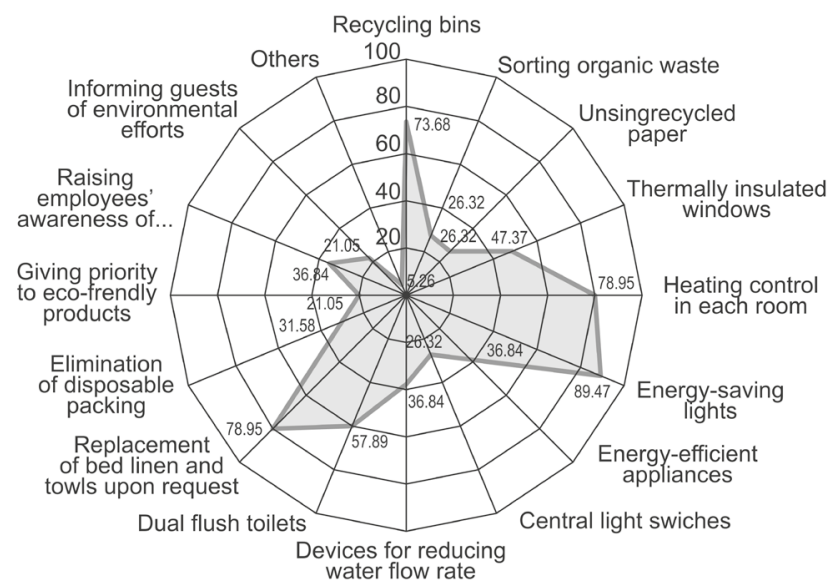

Figure 2. The application of green measures (\%) Source: authors

the same values. More than one-fifth (21.1\%) implemented measures such as using eco-friendly cleaning products, informing guests about environmental efforts and giving preference to products labelled 'eco' (Figure 2).

The biggest problem in using eco-friendly cleaning products and the selection of eco-labelled products is their considerably higher price and price is an important decision factor for managers. In terms of informing guests about environmental efforts, the most common was brochures in a room, eco-signage in bathrooms (31.6\%), as well as information in reception area surroundings, on booking portals $10.5 \%$ ) and the accommodation website (5.3\%).

Almost two-thirds (63.2\%) did not strive for an ecofriendly certificate and a further $21.1 \%$ did not know whether they were interested in obtaining it. Only the remaining $15.8 \%$ would like to obtain an environmental label. Certification is a significant financial cost, the first year for registration and then each year after that for the use of the certificate. In addition, the accommodation facility should have a person responsible for all the requirements and compliance, which is extra money spent. Increased and improved promotion of green management would be appropriate. On the other hand, it is generally true that most facilities in Czechia apply some green management elements but do not have an environmental certificate, which is confirmed in our article. Although there was little interest in the certificate, we can conclude that the facilities found benefits in applying green management elements. In Figure 3, we can see that hotels came closest to making this claim, while apartments chose the answer 'I do not know.' Furthermore, Figure 3 (see p. 108) shows the breakdown by class, i.e., First Class hotels saw benefits in applying green management elements, but some Standard Class were of the opposite opinion. The rest were undecided. 

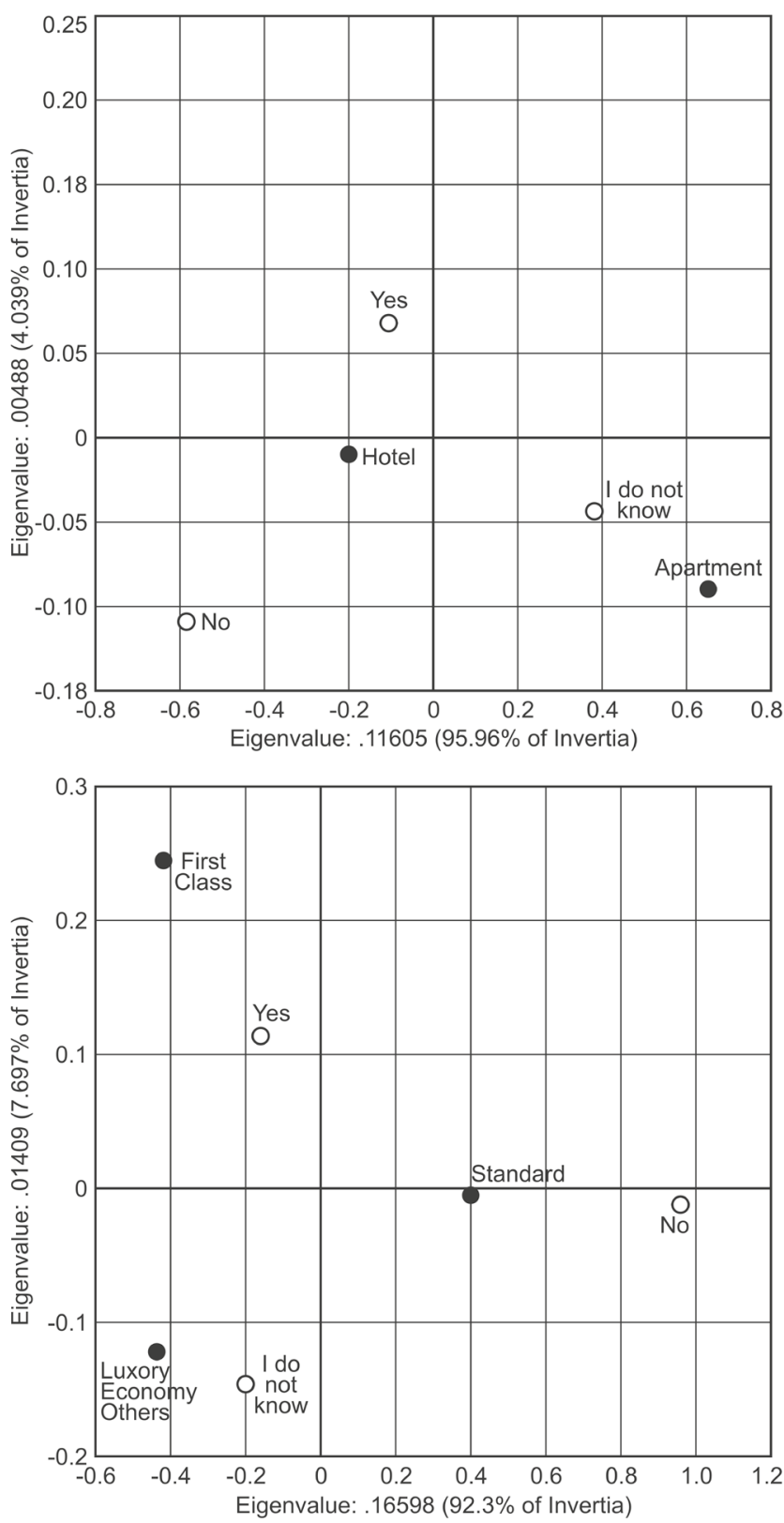

Figure 3. The benefits of green measures Source: authors

In terms of benefits, in addition to environmental improvements $(84.2 \%)$, these included cost reduction $(63.2 \%)$, higher quality of accommodation $(36.8 \%)$, guest preferences $(15.8 \%)$, competitive advantage over other facilities (10.5\%), advertising and promotion, and no other benefits were $5.3 \%$. No facility thought that applying green management would increase their revenue. We agree with authors who suggest that accommodation facilities should definitely invest in green initiatives (Bohdanowicz, 2005; Chan, Lam, 2003; Reddy, Wilkes, 2015). Research shows that there is still a lack of motivation to implement sustainability practices fully. This may be due to the absence of education in the managers, a lack of awareness among the guests, or a shortage of investment to implement green management (Sangeetha, 2020). Research conducted by Kapera and Wszendybył-Skulska (2017) has shown that some hotel guests were interested in eco-friendly activities in Polish hotels, on the other hand, though, more than half paid no attention to ecofriendly elements and measures.

\section{CONCLUSION}

The authors agree that implementing some new green practices, elements and methods requires significant upfront investment to produce less than tangible results, such as improving the reputation of the facility. However, in the long term, investment in these green initiatives would pay off not only in economic terms. It must be taken into consideration that environmental protection and the implementation of green measures require a long-term plan.

This paper has aimed to analyse the application of green measures in selected accommodation facilities in Czechia in the town of Mladá Boleslav and its surroundings. The following research question was posed in connection with the research goal: What green management measures were most often applied in the selected accommodation facilities?

The most frequently used measures were energysaving light bulbs $(89.5 \%)$, heating regulation in each room, and changing bed linen and towels on request only $(79 \%)$. On the other hand, the least prevalent measures included using environmentally-friendly cleaning products, informing guests about environmental efforts, and giving preference to products with an 'eco' label (all $21.1 \%)$. Furthermore, it was demonstrated that higher accommodation categories were eco-friendlier than lower ones and saw the benefits of green management measures.

Concerning the limitations, it must be stated that although the data was collected during 2020, the research did not reflect the impact of the COVID-19 pandemic. Although the authors are aware that the COVID-19 situation might have influenced answers in this case study, they did not incorporate this aspect in their survey. This study is part of large-scale research in Czechia and aims to ensure comparability of data in terms of place and time. Since 2015, the authors have been collecting data in different locations and abroad to compare different regions and cities regarding green management implementation in accommodation facilities. However, the authors also plan to conduct further research that will focus on the impact of the COVID-19 pandemic on implementing green management. 


\title{
PRZYJAZNA DLA ŚRODOWISKA BAZA NOCLEGOWA W MIEŚCIE MLADÁ BOLESLAV W CZECHACH: STUDIUM PRZYPADKU
}

\author{
Petr Scholza (iD, Lenka Červováb ii
}

\footnotetext{
a Politechnika Liberecka, Wydział Ekonomii, Katedra Marketingu i Handlu; https://orcid.org/0000-0002-2637-7119; e-mail: petr.scholz@tul.cz

b Politechnika Liberecka, Wydział Ekonomii, Katedra Marketingu i Handlu; https://orcid.org/0000-0001-7025-7045; e-mail: lenka.cervova@tul.cz
}

Sposób cytowania (styl APA): Scholz, P., Červová, L. (2021). Eco-friendly accommodation facilities in Mladá Boleslav, Czechia: A case study. Turyzm/ Tourism, 31 (2), 103-116. https://doi.org/10.18778/0867-5856.31.2.06

\begin{abstract}
ABSTRAKT
Celem artykułu jest ocena zastosowania różnorodnych rozwiązań w ramach „zielonego" zarządzania w wybranych obiektach noclegowych w Czechach, a konkretnie w mieście Mladá Boleslav i jego okolicach. Podczas badania korzystano z mieszanych metod badawczych, w tym wywiadów częściowo ustrukturyzowanych, przeprowadzonych z kadrą zarządzającą opisywanych obiektów. Wywiady uzupełniono badaniami ankietowymi, koncentrującymi się na problemie zastosowania w obiektach noclegowych rozwiązań nieszkodliwych dla środowiska. Całkowita próba podmiotów uczestniczących w badaniu stanowiła 39,6\% wszystkich obiektów tego typu znajdujących się w mieście i okolicach. Na etapie obróbki danych zastosowano analizę odpowiedniości. Wyniki sugeruja że im wyższa klasa obiektu, tym silniejsza tendencja do korzystania w jego zarządzaniu z metod nieszkodliwych dla środowiska.
\end{abstract}

\section{SŁOWA KLUCZOWE}

„zielone" elementy i rozwiązania, środowisko naturalne, obiekt noclegowy, Czechy

\section{INFORMACJE O ARTYKULE}

Przyjęto:

14 października 2021 r.

Zaakceptowano:

8 listopada $2021 \mathrm{r}$.

Opublikowano:

21 grudnia $2021 \mathrm{r}$.

\section{WSTĘP}

Od kilku dziesięcioleci $\mathrm{w}$ środowisku naturalnym Ziemi zachodzą ogromne zmiany, dużo większe niż kiedykolwiek przedtem. W miarę jak obecna sytuacja zdrowotna stawała się coraz bardziej krytyczny, zaczęła się zwiększać odpowiedzialność człowieka za środowisko. Gdy ludzkość przerywa swoją zwykłą działalność, nikną ślady, które ona pozostawia (Soria, Parra, 2021). Pandemia COVID-19 oddziałuje negatywnie nie tylko na turystykę, ale także na inne obszary działalności gospodarczej. Istnieje zapotrzebowanie na nowoczesne i skuteczne metody zwiększania rentowności sektora turystycznego, ponieważ przychody z tej działalności spadły w skali światowej aż o $74 \%$. Jednocześnie zauważalny stał się nacisk na redukcję kosztów w całym społeczeństwie. Sangeetha i Rebecca (2020) są zdania, że dzięki „zielonemu” podejściu można na dłuższą metę zredukować koszty prowadzenia działalności przy jednoczesnym zwiększeniu wartości dodanej dla społeczeństwa. Turystyka wnosi $10 \%$ do światowego PKB, lecz także odpowiada za 5\% globalnej emisji $\mathrm{CO}_{2}$, z czego $1 \%$ przypisuje się obiektom noclegowym (Khatter, White, Pyke, McGrath, 2021). Zasoby energetyczne Ziemi nie są nieograniczone, w związku z czym ich ochrona powinna stać się ważnym elementem „zielonego" zarządzania każdym obiektem (Tiwari, Dambhare, Tripathi, 2020). Jednakże - jak zauważają Sadom, Quoquab i Mohammad (2021) - główną przyczyną problemu nadmiernej konsumpcji w przemyśle hotelarskim jest nieod powiedzialne zachowanie konsumentów, w tym przypadku gości obiektu. Ekologiczne produkty i usługi okazały się dużym sukcesem, gdyż stanowiły odpowiedź na zwiększoną wrażliwość gości spowodowaną troską o obecny stan środowiska (Gupta, Satyabhusan, Mishra, 2019). Gil-Soto, Armas-Cruz, Morini-Marrero i Ramos-Henríquez (2019) nadmieniają że „zielone” reklamy są obecnie bardzo popularne w branży hotelarskiej i jak powszechnie wiadomo, propagują zrównoważone zachowania oraz konsumpcję przyjazną dla środowiska. W swoich badaniach Moise, Gil-Saura i Molina (2021) podkreślają jak ważne jest, by obiekty noclegowe w krajach rozwijających się wdrażały „zielone" rozwiązania w celu poprawy swojego wizerunku oraz zwiększenia poziomu zaufania i satysfakcji gości, a zarazem podtrzymania długoterminowych relacji z nimi i zdobywania nowych klientów. 


\section{PRZEgLĄD Literatury}

Ochrona środowiska jest obecnie naglącą kwestia, która przyciąga wiele uwagi i jest dyskutowana w odniesieniu do wszystkich dziedzin życia (Graci, Dodds, 2008; Petkova, 2017; Trejos, 2013). Wysiłki zmierzające do zminimalizowania negatywnych skutków działań człowieka na naturę podejmowane są także $\mathrm{w}$ branży hotelarskiej poprzez „zielone” zarządzanie. Przedstawiciele branży hotelarskiej przyjmują na siebie coraz większą odpowiedzialność za zrównoważony rozwój środowiska naturalnego, który staje się ich głównym celem. W obiektach noclegowych należy bardziej skupić się na zużyciu prądu i wody, gdyż produkowanie odpadów wiąże się bezpośrednio z korzyściami finansowymi, jakie płyną ze skutecznego działania (Kapera, 2018). Wśród kadry zarządzającej większością obiektów noclegowych wzrasta świadomość ekologiczna i umacnia się przekonanie, że apartamenty i pensjonaty powinny być bardziej zaangażowane w zrównoważone działania, a co za tym idzie - przyczyniać się do polepszenia stanu środowiska naturalnego zarówno na poziomie lokalnym, jak i ogólnokrajowym (Tran, 2009). Wznoszenie nowych obiektów noclegowych skutkuje ograniczaniem przestrzeni życiowej miejscowej fauny i flory, więc ważne jest, by mieć „zielone” podejście do problemu, co pomoże złagodzić jego negatywne skutki (Kalábová, Abrhám, 2016). Przyszłość branży turystyczno-hotelarskiej opiera się na zasadach ekologii i odpowiedzialności społecznej (Tran, 2009). Zachowanie środowiska naturalnego $\mathrm{w}$ niepogorszonym stanie wydaje się najlepszym wyborem, który zagwarantuje dobre samopoczucie wszystkim interesariuszom, a w szczególności gościom hotelowym. Właśnie dlatego tak ważne jest prowadzenie działalności noclegowej z wykorzystaniem procesów nieszkodzących środowisku, a co za tym idzie - przyczynianie się do osiągnięcia lepszych wyników w całej branży, bez jednoczesnego stwarzania zagrożenia dla rentowności czy wiarygodności finansowej obiektu (Dani, Tiwari, Negi, 2021). Pojęcie zarządzania środowiskowego (zwanego także „zielonym”) odnosi się do filozofii, technologii oraz metod zarządzania organizacją, mających na celu optymalizację jej wpływu na środowisko. Zasadniczymi celami zarządzania środowiskowego są oszczędne użycie surowców, energii oraz innych zasobów, jak również redukcja czynników stanowiących obciążenie dla środowiska. Wreszcie, co równie ważne, jedną z zalet tego podejścia jest zróżnicowanie konkurencji. Aby można było prowadzić obiekt noclegowy nieszkodliwy dla środowiska, nie są potrzebne zaświadczenia ani ogromne inwestycje początkowe. W swoim opracowaniu Sangeetha i Rebecca (2020) potwierdzają tezę, że na dłuższą metę obiekty noclegowe, dzięki wdrażaniu ekologicznie zrównoważonych rozwiązań, obniżają koszty prowadzenia działalności, a ponadto zwiększa się ich stopa zwrotu z inwestycji. Omune, Kambona, Wadongo i Wekesa (2021) zauważaja, że rząd powinien zapewnić wsparcie finansowe obiektom, w których wdrażane są kosztowne rozwiązania proekologiczne.

Należy zaznaczyć, że nie istnieje ujednolicona definicja obiektów noclegowych przyjaznych dla środowiska. Potencjalny gość ma do wyboru dwa rodzaje obiektów skoncentrowanych na stosowaniu rozwiązań z zakresu „zielonego" zarządzania. Pierwszy typ to obiekty, którym udało się spełnić surowe kryteria certyfikacji środowiskowej i otrzymać odpowiednie zaświadczenia. Drugą grupę stanowią budynki środowiskowo aktywne i przyjazne, w których wprowadzane są liczne elementy "zielonego" zarządzania, ale ze względów finansowych niemające certyfikatów środowiskowych. W praktyce oznacza to, że dany obiekt nie musi uzyskać żadnych zaświadczeń, by był przyjazny dla środowiska i mógł pomagać $\mathrm{w}$ poprawie jakości otoczenia. Właśnie $\mathrm{w}$ taki sposób autorzy artykułu pojmują obiekty noclegowe nieszkodliwe dla środowiska. Podobnie stowarzyszenie Green Accommodation Association definiuje „zielone obiekty noclegowe" jako działające w sposób eco-friendly (Green Accommodation Association, 2015). Dzięki takim działaniom mogą one zwiększać świadomość gości dotyczącą „zielonego" zarządzania, a tym samym doprowadzać do wzrostu ogólnego zapotrzebowania na elementy proekologiczne. Hou i Wu (2021) twierdza, że jednym z najważniejszych powodów wdrażania ekologicznych zachowań w obiektach noclegowych jest satysfakcja gości. Autorzy niniejszego artykułu zgadzają się $\mathrm{z}$ tą tezą jedynie $\mathrm{w}$ niewielkim stopniu, ponieważ w Czechach jest tylko pięć takich obiektów, co stanowi zaledwie 0,053\% wśród 9383 obiektów noclegowych. Goście kierują się przede wszystkim ceną nie „zielonymi" rozwiązaniami. Praktyka stosowania takich etykiet, jak „zielony” czy "przyjazny dla środowiska” jako chwytu marketingowego wciąż jest powszechna w wielu miastach i miasteczkach na całym świecie. Menedżerowie obiektów noclegowych utrzymuja że są one przyjazne dla środowiska, choć personel nie robi $\mathrm{w}$ tym kierunku nic poza wywieszeniem odpowiedniej tabliczki i deklarowaniem rzekomej „zieloności” (Pizam, 2009).

Wiele rozwiązań ekologicznych stosuje się w celu zmniejszenia zużycia energii (Wan, Chan, Huang, 2017), wody (Gössling, Hall, Scott, 2015; Reddy, Wilkes, 2015), środków chemicznych, materiałów biurowych, ograniczenia produkcji odpadów, przy jednoczesnym zwiększeniu udziału materiałów naturalnych i estetyki środowiskowej, a także obniżeniu hałasu i emisji szkodliwych substancji (Chen, Hsieh, 2011). W obiektach noclegowych różnie podchodzi się do wyboru metod redukcji kosztów. W niektórych podejmowane są decyzje na podstawie najpilniejszych bieżących potrzeb, $\mathrm{w}$ innych wybiera się rozwiązania przynoszące największe oszczędności najniższym kosztem. Odpowiedzialność 
środowiskowa przyjmuje wiele różnych postaci, $\mathrm{w}$ tym zarządzania energią i zabiegów związanych z przetwarzaniem odpadów, gaszenia światła oraz monitorowania użycia klimatyzatorów (Bansal, Roth, 2000).

Przy zamawianiu surowców i produktów właściciele obiektów noclegowych powinni dawać pierwszeństwo regionalnym produktom i specjałom, starać się wspierać lokalną infrastrukturę, zapewniać ustawiczne kształcenie personelu w kwestii wykorzystania nowych technologii, jak również przestrzegać zasad zarządzania środowiskowego. Powinni również w przyjazny sposób podnosić świadomość ekologiczną gości. Ponadto konieczne są segregacja odpadów oraz ponowne używanie przetworzonych surowców. Właściwe zarządzanie odpadami może pomóc $\mathrm{w}$ zmniejszeniu ilości wytwarzanych śmieci, oszczędzaniu surowców, zasobów naturalnych oraz energii, a jednocześnie w zachowaniu zasobów finansowych. Zasadniczym wymogiem ograniczenia ilości odpadów oraz ich skutecznego ponownego wykorzystania jest oparta na rodzaju surowca segregacja na metal, papier, szkło, tworzywa sztuczne, tzw. odpady bio i zużyty olej (Patúšs, Gúčik, 2005). Pomimo licznych praktyk proekologicznych, stosowanych np. w codziennym gospodarowaniu obiektem, niektóre zabiegi nie przynoszą aż tak dużych zmian, jak można by oczekiwać, przy czym część z nich może stanowić dla personelu sprzątającego nadmierne obciążenie (Choy, Cheng, Yu, 2021).

Jako że zapobieganie marnowaniu jedzenia bądź jego ograniczanie jest jednym $\mathrm{z}$ priorytetów $\mathrm{w}$ procesie zmniejszania ilości odpadów, powinno się ustalić konkretne zalecenia dla branży turystyczno-hotelarskiej. Komisja Europejska szacuje, że rocznie wyrzuca się ok. $88 \mathrm{mln}$ ton jedzenia o wartości 143 mld euro. Europejskie restauracje generują $\mathrm{w}$ przybliżeniu $12 \%$ całkowitej ilości zmarnowanego jedzenia, co oznacza, że rocznie produkują go ponad $10 \mathrm{mln}$ ton. Przekłada się to na ponad 17 mld euro wydawanych niepotrzebnie każdego roku (Ratinger i in., 2020).

Zarządzanie aprowizacją powinno wiązać się m.in. z właściwymi warunkami przechowywania żywności. Wskazane jest również monitorowanie zmian w konsumpcji. Zaleca się, by w obiektach były prowadzone rejestry ilości oraz rodzajów generowanych odpadów spożywczych (Priefer, Jörissen, Bräutigam, 2016). Wielkość porcji również należy kontrolować. Obiekty gastronomiczne powinny przetwarzać żywność na podstawie norm żywnościowych, w sposób wydajny i bez marnowania produktów. Należy zmniejszyć wielkość porcji, szczególnie w przypadku żywności, z której powstaje najwięcej odpadów. Zostało to potwierdzone m.in. dzięki analizie dotyczącej odpadów spożywczych $\mathrm{w}$ obiektach gastronomicznych typu bufetowego. Badanie to udowodniło, że więcej jedzenia marnuje się w bufetach obiadowych niż w bufetach śniadaniowych, ponieważ na talerzach klientów podczas obiadu zostaje więcej jedzenia (Juvan, Grün, Zabukovec Baruca, Dolnicar, 2021).

Na koniec należy wspomnieć o tym, że obiekty powinny zwiększać świadomość gości na temat negatywnych skutków marnowania jedzenia (Betz, Buchli, Göbel, Müller, 2015; Engstrom, Carlsson-Kanyama, 2004; Pirani, Arafat, 2016). W niektórych obiektach noclegowych i restauracjach zachęca się klientów, by zabierali niedojedzone posiłki do domu w celu późniejszego spożycia (Zuraikat, Roe, Smethers, Rolls, 2018). Trzeba także wdrożyć procedury, które zagwarantowałyby racjonalne wykorzystanie resztek $\mathrm{w}$ celu minimalizacji ilości produkowanych odpadów, np. przygotowywanie ich i przekazywanie członkom personelu, rozdawanie zupy oraz innych rodzajów żywności instytucjom charytatywnym itp. (Awasthi i in., 2018).

\section{DANE I METODY BADAŃ}

Celem niniejszego artykułu jest analiza zastosowania "zielonych" rozwiązań w wybranych obiektach noclegowych w Czechach, na terenie miasta Mladá Boleslav oraz w jego okolicy. Nawiązując do celu badawczego postawiono następujące pytanie: jakie rozwiązania w zakresie zarządzania środowiskowego są najczęściej wdrażane $\mathrm{w}$ wybranych obiektach noclegowych?

Na potrzeby niniejszego opracowania użyto danych źródłowych zebranych za pomocą jakościowych, częściowo ustrukturyzowanych wywiadów z członkami kadry zarządzającej obiektów noclegowych oraz badań ankietowych. Wywiady przeprowadzono $\mathrm{w}$ mieście Mladá Boleslav i okolicach $(n=19)$ między czerwcem a grudniem 2020 r. Całkowita próba obiektów biorących udział w badaniu stanowiła 39,6\% wszystkich tego typu miejsc noclegowych na tym terenie. Dodatkowe informacje zdobyto dzięki badaniom ankietowym przeprowadzonym drogą e-mailową bądź telefoniczną. Kwestionariusz ankiety zawierał 12 pytań, z których pierwsze pięć miało charakter ogólny, a ich celem była identyfikacja respondentów, w tym przyporządkowanie obiektu noclegowego do odpowiedniej kategorii (Tiwari, Dambhare, Tripathi, 2020; Yoon, Sauri, Rico, 2021), inne zaś dotyczyły stosowania „zielonego" zarządzania. Jednym z najważniejszych było pytanie o to, czy dany obiekt w ogóle wdrożył koncepcję „,zielonego" zarządzania (Rawashdeh, Al-Ababneh, 2021; Tourkolias, Kontogianni, Damigos, Skourtos, 2020). Kolejna grupa pytań dotyczyła indywidualnych elementów i rozwiązań w obrębie „zielonego" zarządzania (Moise, Gil-Saura, Molina, 2021; Sangeetha, Rebecca, 2020; Švec i in., 2021). Pytania sformułowano w taki sposób, by respondenci mogli wybrać kilka spośród możliwych odpowiedzi. Za pomocą kwestionariusza badano także, czy z perspektywy obiektów noclegowych wdrożenie 
"zielonego" zarządzania okazało się zaletą i czy będą się one ubiegać o wydanie odpowiedniego certyfikatu. Na koniec zadano pytania na temat różnych sposobów przekazywania gościom informacji o proekologicznych działaniach obiektu. Wszyscy uczestnicy zostali poinformowani o celu badania oraz o poufności udzielonych odpowiedzi i dobrowolnie zgodzili się na udział w nim.

Do oceny zgromadzonych danych autorzy zastosowali metodę analityczna, tzw. analizę odpowiedniości (inaczej: analizę korespondencji, CA). Dzięki wykorzystaniu graficznych narzędzi analizy odpowiedniości można opisać związek pomiędzy zmiennymi nominalnymi i porządkowymi, a także otrzymać graficzne przedstawienie tej relacji w przestrzeni wielowymiarowej, które jest łatwiejsze do zrozumienia. Analiza dostarcza również dalszych dowodów na istnienie zależności pomiędzy zmiennymi.

Analiza odpowiedniości jest wielowariantową metodą statystyczną. Pojęciowo jest ona zbliżona to analizy głównych składowych, jednak stosuje się ją raczej do badania danych kategorycznych niż ciągłych. Podobnie jak w przypadku analizy głównych składowych stanowi ona sposób zademonstrowania lub podsumowania zbioru danych w dwuwymiarowej formie graficznej (Zámková, Prokop, 2014). Wszystkie dane powinny być wartościami nieujemnymi i znajdować się na tej samej skali, aby można było zastosować analizę odpowiedniości. W metodzie tej wiersze i kolumny traktuje się równoważnie. Tradycyjnie stosuje się ją w przypadku tablic kontyngencji, ponieważ rozkłada ona na czynniki ortogonalne statystyki chi-kwadrat związane z takimi tablicami. Odległość pomiędzy poszczególnymi punktami określa się jako odległość chi-kwadrat. Odległość pomiędzy rzędem $i$ oraz rzędem $i^{\prime}$ wyznacza się za pomocą następującego wzoru:

$$
D\left(i, i^{\prime}\right)=\sqrt{\sum_{j=1}^{c} \frac{\left(r_{i j}-r_{i j}\right)^{2}}{c_{j}}}
$$

gdzie $r_{i j}$ to elementy macierzy $R$ profilów wierszy, z kolei wagi $c_{j}$ korespondują z elementami wektora obliczeniowego kolumny $c T$, który jest równy średniemu profilowi kolumny (centroid) spośród profilów kolumn w przestrzeni wielowymiarowej. Odległość pomiędzy kolumnami $j$ oraz $j^{\prime}$ definiuje się w podobny sposób, wagi zaś korespondują z elementami wektora obliczeniowego wiersza $r$ oraz sumy wszystkich wierszy.

Wykorzystując analizę odpowiedniości, obserwujemy związek pomiędzy pojedynczymi kategoriami dwóch kategorycznych zmiennych. Wynik takiej analizy to mapa korespondencji, zawierająca osie uproszczonego układu współrzędnych, na którym poszczególne kategorie obydwu zmiennych prezentuje się w formie graficznej. Celem takiej analizy jest redukcja przestrzeni wielowymiarowej profilów kolumn i wierszy, a także zachowanie jak największej ilości oryginalnych danych. Każdy wiersz i każdą kolumnę na tablicy korespondencji można pokazać w wymiarze przestrzeni $c$ (oraz - odpowiednio - r) przy użyciu współrzędnych równych wartościom odpowiadających im profilów. Współrzędne wierszy i kolumn na każdej osi są tak wyskalowane, by osiągnąć inercję równą inercji podstawowej wzdłuż tej osi - są to podstawowe współrzędne wiersza i kolumny (Hebák i in., 2007).

\section{WYNIKI I DYSKUSJA}

Łącznie w ankiecie wzięli udział przedstawiciele 19 obiektów noclegowych. Spośród objętych badaniem obiektów niemal 3/4 stanowiły hotele (73,7\%). W mniejszym stopniu uwzględniono także apartamenty $(15,8 \%)$ i pensjonaty (10,5\%). Jeśli chodzi o hotele, najczęściej były to obiekty klasy standard (52,6\%), rzadziej klasy pierwszej (15,8\%), luksusowej (10,5\%) i ekonomicznej $(10,5 \%)$. Obiekty klasy turystycznej nie zostały uwzględnione w badaniu. Należy także zaznaczyć, że dwóch obiektów nie zaliczono do żadnej klasy, ponieważ czeskie prawodawstwo nie przewiduje takiego obowiązku (dla apartamentów i pensjonatów). Autorzy opracowania zdają sobie sprawę, że liczba obiektów różnych klas nie jest taka sama, jednak odzwierciedla to sytuację w mieście Mladá Boleslav i okolicy. W ponad połowie obiektów (52,6\%) znajdowało się 21-50 pokoi, w 42,1\% - 5-20 pokoi, natomiast w niespełna $1 / 10$ (5,3\%) - 51-100 pokoi. Hotele, w których było ponad 100 pokoi, nie zostały uwzględnione $\mathrm{w}$ badaniu. $\mathrm{W}$ ponad połowie obiektów $(57,9 \%)$ nie wdrożono idei ,zielonego" zarządzania, prawie w $1 / 3(31,6 \%)$ zrobiono to, zaś w przypadku pozostałych $10,5 \%$ ich przedstawiciele nie potrafili odpowiedzieć na to pytanie. Nie oznacza to jednak, że w obiektach tych przynajmniej częściowo nie przestrzegano zasad "zielonego" zarządzania.

W ponad 3/4 obiektów noclegowych $(84,2 \%)$ objętych badaniem zdecydowano się na segregację odpadów. Choć może się to wydawać sporą liczba, należy zaznaczyć, że po pierwsze każdy taki obiekt jest prawnie zobowiązany do segregacji odpadów, nawet jeśli nie stara się o przyznanie „zielonego" certyfikatu, a po drugie jest to najmniej kosztowny sposób ochrony środowiska. W ponad połowie obiektów (57,9\%) udało się zmniejszyć zużycie wody i energii elektrycznej, natomiast w prawie połowie $(42,1 \%)$ starano się ograniczyć zużycie środków chemicznych. W ponad $1 / 4(26,3 \%)$ podjęto wysiłki zmierzające do edukowania członków personelu i gości oraz wydawania odpowiednich komunikatów. We wszystkich badanych obiektach wdrożono przynajmniej jeden element „zielonego" zarządzania (rysunek 1). 


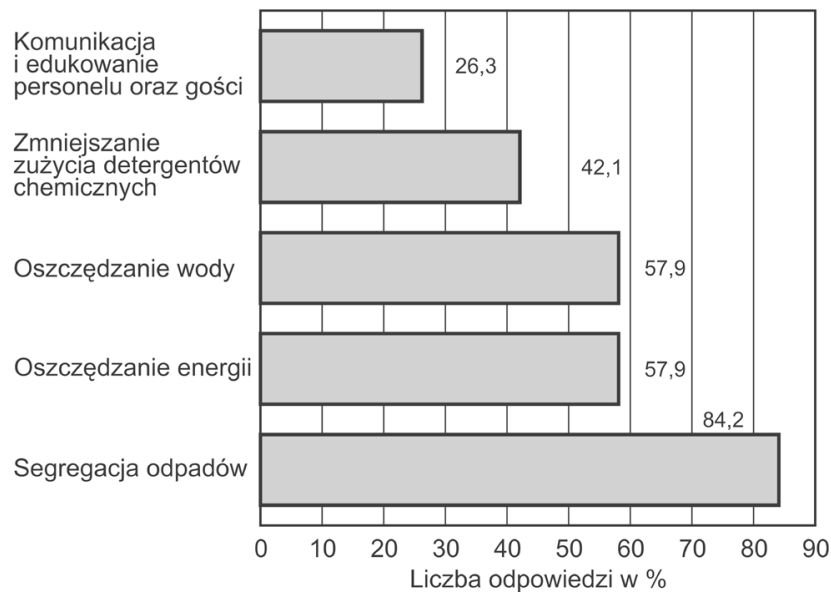

Rysunek 1. Wdrożenie zasad zarządzania środowiskowego Źródło: opracowanie własne

Autorzy niniejszego opracowania uważaja że w badanych obiektach powinno się poprawić komunikację z pracownikami i klientami w kwestiach ochrony środowiska. Najczęściej stosowaną metodą było użycie energooszczędnych żarówek (89,5\%), dzięki którym można zaoszczędzić znaczącą ilość energii. Są one jednym z tańszych rozwiązać, od których można zacząć przemianę $\mathrm{w}$ „zielony obiekt noclegowy”. Na przykład w średniej wielkości hotelu, w którym znajduje się ok. 200 żarówek, dzięki ich całkowitej wymianie można zaoszczędzić ponad 1,1 mln koron czeskich.

Drugim najczęściej wybieranym w wielu obiektach sposobem była regulacja ogrzewania w każdym pokoju oraz wymiana pościeli i ręczników wyłącznie na życzenie gości (79\%). Regulacja ogrzewania pokazuje, jak ważne jest oszczędzanie prądu. Jeśli jakiś pokój nie jest akurat zajęty przez gości, a tylko gotowy na ich przybycie, włączanie w nim klimatyzacji czy ogrzewania nie jest konieczne. Wystarczy je uruchomić kilka godzin przed przyjazdem klientów. W 73,7\% obiektów wykorzystuje się pojemniki do segregacji. W ponad połowie z nich $(57,9 \%)$ sposobem na zmniejszenie zużycia wody jest montaż toalet $\mathrm{z}$ systemem podwójnego spłukiwania, który pozwala użytkownikom na wybór pomiędzy użyciem trzech lub sześciu litrów wody. Co dziwne, jedynie w 36,8\% obiektów stosowano krany z perlatorami, wodooszczędne krany bądź wodooszczędne słuchawki prysznicowe. Za sprawą wodooszczędnego kranu można zmniejszyć zużycie wody w umywalce łazienkowej mniej więcej o 70\%, bez jednoczesnego pogorszenia komfortu użytkowania. Z kolei wpływu wodooszczędnych słuchawek prysznicowych na zmniejszenie zużycia wody nie da się zmierzyć tak precyzyjnie, jak w przypadku kranów tego rodzaju. W porównaniu do tradycyjnych słuchawek te wodooszczędne mogą obniżyć zużycie wody o maksymalnie $40 \%$, tj. zmniejszyć tempo jej przepływu do 12-15 litrów na minutę. Podobnie jak w przypadku oświetlenia koszty wymiany tych urządzeń nie są wysokie. Wodooszczędny kran czy wodooszczędna słuchawka prysznicowa kosztują ok. 500 koron czeskich. W niemal połowie obiektów $(47,4 \%)$ stosowano okna z izolacją termiczna, które w zimie zatrzymują ciepło w pomieszczeniu, podczas gdy żądana temperatura jest utrzymywana dzięki klimatyzacji.

Tylko w 36,8\% obiektów zdecydowano się na edukację pracowników w zakresie "zielonego” zarządzania. Oznaczało to np., że prowadzono sesje szkoleniowe na ten temat bądź kierownictwo wydawało specjalne komunikaty dla pracowników, dotyczące m.in. segregacji odpadów, konieczności wyłączania światła, niepozostawiania bez potrzeby włączonych klimatyzatorów bądź grzejników.

$\mathrm{W}$ prawie $1 / 3$ obiektów nie korzystano $\mathrm{z}$ jednorazowych opakowań na masło, dżemy, szampon itp. Rezygnacja z tego typu opakowań jest jednym z podstawowych kroków w dążeniu do realizacji idei „zielonego" zarządzania, ponieważ pozwala uniknąć niepotrzebnego zużycia plastiku oraz konieczności jego późniejszej segregacji i przetwarzania. Problem polega na tym, że ponad $90 \%$ negatywnego wpływu na środowisko, związanego z produkcja, wykorzystaniem oraz pozbywaniem się plastiku, nie jest uwzględniane w jego cenie rynkowej. Kolejną kwestią jest koszt zarządzania odpadami wliczany w podatki oraz opłaty. Najbardziej znaczącą ilościowo pozycją jest naprawa szkód spowodowanych przez plastik $\mathrm{w}$ środowisku naturalnym, w tym w oceanach, jak również stracone przychody $w$ rybołówstwie oraz turystyce wywołane zanieczyszczeniem wód. W ponad 1/4 obiektów noclegowych $(26,3 \%)$ segregowano $t z w$. bioodpady. Taki sam wynik uzyskano w odniesieniu do używania przetworzonego papieru oraz stosowania w pomieszczeniach centralnych wyłączników światła bądź czujników ruchu. W ponad $1 / 5$ obiektów $(21,1 \%)$ stosowano takie metody, jak: wykorzystywanie środków czyszczących nieszkodliwych dla środowiska, informowanie gości o wysiłkach proekologicznych oraz preferowanie produktów opisanych jako ekologiczne (rysunek 2).

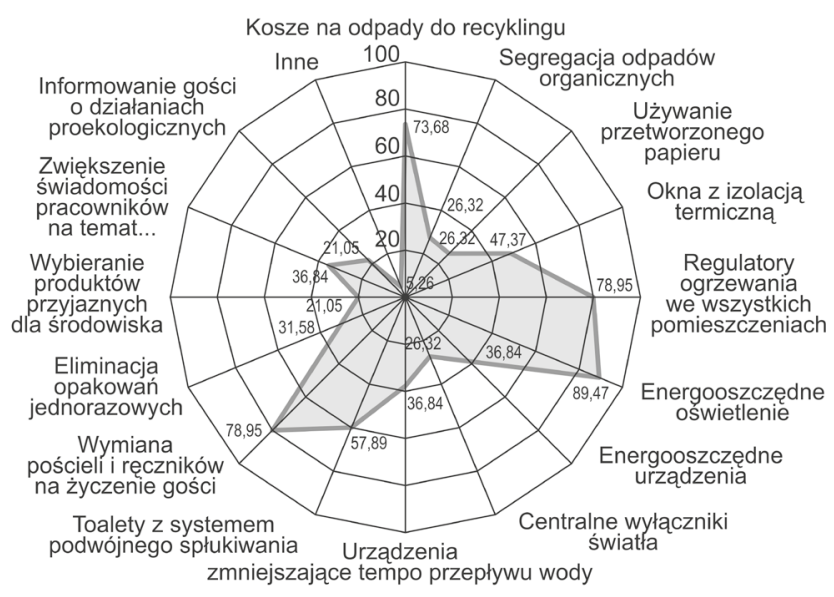

Rysunek 2. Zastosowanie „zielonych” rozwiązań (\%) Źródło: opracowanie własne 
Największym problemem związanym z używaniem środków czyszczących nieszkodliwych dla środowiska oraz z wyborem produktów oznaczonych jako ekologiczne jest ich zdecydowanie wyższa cena, a koszty są ważnym czynnikiem branym pod uwage przez kierownictwo obiektów noclegowych przy podejmowaniu decyzji o zakupie. O działaniach proekologicznych najczęściej informowano gości za pomocą broszur pozostawianych w pokojach, odpowiednich oznakowań w łazienkach (31,6\%), jak również informacji umieszczanych $\mathrm{w}$ pobliżu recepcji, $\mathrm{w}$ portalach bookingowych $(10,5 \%)$ oraz na stronach internetowych obiektów $(5,3 \%)$.

W 2/3 obiektów $(63,2 \%)$ nie podejmowano starań, by otrzymać certyfikat „przyjazny dla środowiska”, a w odniesieniu do kolejnych $21,1 \%$ nie wiadomo, czy są nim zainteresowane. Jedynie pozostałe $15,8 \%$ respondentów chciałoby, aby ich obiekty uzyskały takie oznaczenie. Certyfikacja ekologiczna stanowi znaczący koszt finansowy, w pierwszym roku ze względu na rejestrację, w kolejnych latach zaś w związku z używaniem certyfikatu. Ponadto w obiekcie należy zatrudniać osobę odpowiedzialną za spełnianie wszystkich wymagań, co oznacza dalsze wydatki. Wzmożona i usprawniona promocja „zielonego" zarządzania także byłaby w tym wypadku stosowna. Niemniej jednak większość obiektów noclegowych na terenie Czech wprowadza pewne elementy „zielonego" zarządzania, choć nie ma odpowiedniego certyfikatu, co potwierdzają dane zgromadzone na potrzeby niniejszego artykułu. Choć zainteresowanie certyfikacją było niewielkie, można wyciągnąć wniosek, że właściciele obiektów uznali za korzystne wdrożenie elementów „zielonego" zarządzania. Na rysunku 3 widać, że przedstawiciele hoteli byli najbliżej takiego stwierdzenia, podczas gdy respondenci reprezentujący apartamenty najczęściej wybierali odpowiedź „Nie wiem”. Ponadto na rysunku 3 pokazano rozkład ze względu na klasę obiektu, tj. przedstawiciele hoteli pierwszej klasy dostrzegali korzyści płynące z wdrażania elementów „zielonego" zarządzania, a reprezentanci niektórych obiektów klasy standard mieli odmienną opinię na ten temat. Respondenci z pozostałych obiektów byli w tej kwestii niezdecydowani.

Jeśli chodzi o korzyści, to poza poprawą stanu środowiska naturalnego $(84,2 \%)$ wymieniano także redukcję kosztów (63,2\%), zwiększenie jakości zakwaterowania $(36,8 \%)$, preferencje gości $(15,8 \%)$, przewagę konkurencyjną nad innymi obiektami (10,5\%), reklamę i promocję. W 5,3\% przypadków uznano, że wdrożenie proekologicznych rozwiązań w ogóle nie przynosi korzyści. $\mathrm{W}$ żadnym z badanych obiektów nie stwierdzono, że wiąże się to ze wzrostem przychodów.

Autorzy niniejszego artykułu zgadzają się z badaczami, którzy sugeruja że w obiektach noclegowych
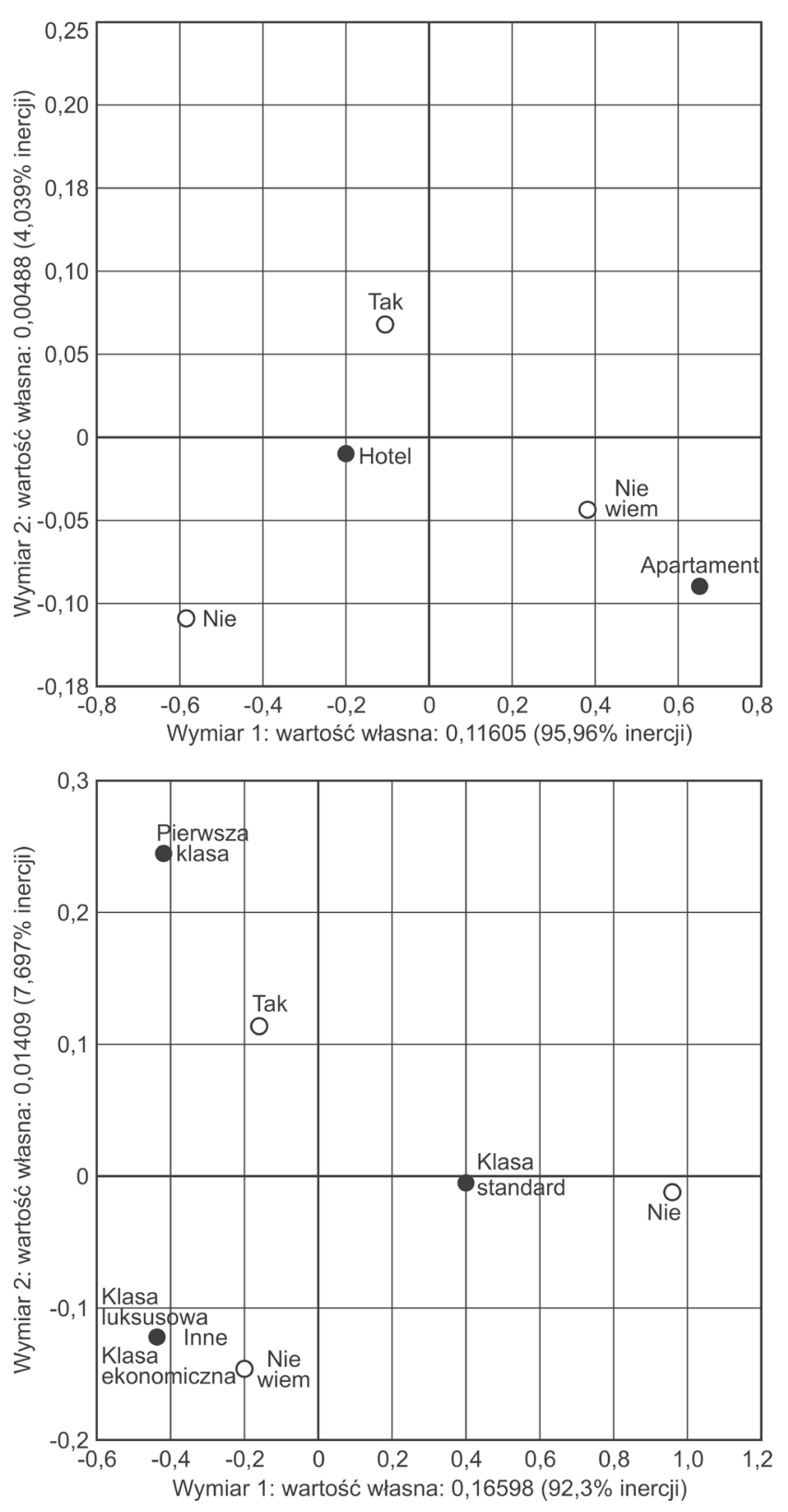

Rysunek 3. Korzyści płynące z „zielonych” rozwiązań Źródło: opracowanie własne

zdecydowanie należy inwestować w „zielone” inicjatywy (Bohdanowicz, 2005; Chan, Lam, 2003; Ready, Wilkes, 2015). Jak pokazują badania, wciąż brakuje motywacji, by w pełni wdrożyć zrównoważone praktyki. Powodem może być brak odpowiedniej edukacji wśród menedżerów, brak świadomości środowiskowej gości bądź niedobór inwestycji pozwalających na przestrzeganie zasad „zielonego" zarządzania (Sangeetha, 2020). Jak pokazały badania przeprowadzone przez Kaperę i Wszendybył-Skulską (2017), choć niektórzy goście polskich hoteli wykazywali zainteresowanie działaniami przyjaznymi dla środowiska podejmowanymi w obiektach, ponad połowa z tych osób nie zwracała w ogóle uwagi na tego typu elementy i zabiegi. 


\section{WNIOSKI}

Autorzy opracowania zgadzają się, że niektóre "zielone” praktyki, elementy i metody wymagają znaczących, wstępnych nakładów, choć przynoszą nie do końca namacalne rezultaty, takie jak np. poprawa reputacji obiektu. Jednakże na dłuższą metę inwestowanie w proekologiczne inicjatywy jest opłacalne nie tylko z ekonomicznego punktu widzenia. Należy wziąć pod uwagę, że ochrona środowiska i wdrażanie „zielonych” rozwiązań wymagają długofalowego planu.

Celem artykułu była analiza wdrażania „zielonych” rozwiązań w wybranych obiektach noclegowych w Czechach, w mieście Mladá Boleslav i jego okolicach. Autorzy postawili następujące pytanie badawcze: jakie rozwiązania łączące się z ,zielonym” zarządzaniem były wdrażane najczęściej w wybranych obiektach noclegowych?

Najczęściej stosowanymi rozwiązaniami okazały się: użycie energooszczędnych żarówek (89,5\%), regulatory ogrzewania w każdym pomieszczeniu oraz wymiana pościeli i ręczników wyłącznie na życzenie gości (79\%). Najrzadziej spotykanymi rozwiązaniami były m.in.: wykorzystanie środków czystości przyjaznych dla środowiska, informowanie gości o działaniach proekologicznych podejmowanych w obiekcie oraz preferowanie produktów oznaczonych jako ekologiczne (wszystkie uzyskały wynik 21,1\%). Ponadto wykazano, że obiekty o wyższym standardzie były bardziej proekologiczne niż te o niższym i dostrzegano w nich korzyści płynące z wdrażania rozwiązań związanych z „zielonym” zarządzaniem.

W związku z ograniczeniami należy zauważyć, że mimo gromadzenia danych w 2020 r. badanie nie odzwierciedla oddziaływania pandemii COVID-19 na branżę. Choć autorzy są świadomi, że związana z pandemią sytuacja mogła wpłynąć na odpowiedzi udzielane na potrzeby niniejszego studium przypadku, nie uwzględnili tego aspektu w stworzonej przez siebie ankiecie. Niniejsze opracowanie stanowi część badania prowadzonego na terenie Czech na dużą skalę. Autorzy dążą do tego, by zapewnić porównywalność danych względem miejsca i czasu. Od 2015 r. gromadzą oni dane pochodzące z różnych lokalizacji, a także z zagranicy, pozwalające na porównanie poszczególnych regionów i miast pod względem wdrażania zasad "zielonego" zarządzania w obiektach noclegowych. Autorzy planują także przeprowadzenie dalszych badań, które skupiłyby się na wpływie pandemii COVID-19 na ten proces.

\section{REFERENCES/BIBLIOGRAFIA}

Awasthi, M.K., Wang, Q., Wang, M., Chen, H., Ren, X., Zhang, Z. (2018). In-vessel co-composting of food waste employing enriched bacterial consortium. Food Technology \& Biotechnology, 56 (1), 83-89. https://doi.org/10.17113/ftb.56.01.18.5439
Bansal, P., Roth, K. (2000). Why companies go green: A model of ecological responsiveness. Academy of Management Journal, 43 (4), 717-736. https://doi.org/10.5465/1556363

Betz, A., Buchli, J., Göbel, C., Müller, C. (2015). Food waste in the Swiss food service industry: Magnitude and potential for reduction. Waste Management, 35, 218-226. https://doi. org/10.1016/j.wasman.2014.09.015

Bohdanowicz, P. (2005). European hoteliers' environmental attitudes: Greening the business. Cornell Hotel and Restaurant Administration Quarterly, 46 (2), 188-204. https://doi. org/10.1177/0010880404273891

Chan, W.W., Lam, J.C. (2003). Energy-saving supporting tour-ism sustainability: A case study of hotel swimming pool heat pump. Journal of Sustainable Tourism, 11 (1), 74-83. https://doi. org/10.1080/09669580308667194

Chen, H., Hsieh, T. (2011). An environmental performance assessment of the hotel industry using an ecological footprint. Journal of Hospitality Management and Tourism, 2 (1), 1-11.

Choy, M., Cheng, J., Yu, K. (2021). Evaluating the environmental sustainability strategies of the housekeeping department: the case of an international hotel chain in Hong Kong. Tourism Critiques, ahead-of-print. https://doi.org/10.1108/ TRC-01-2021-0001

Dani, R., Tiwari, K., Negi, P. (2021). Ecological approach towards sustainability in hotel industry. Materials Today: Proceedings, ahead-of-print. https://doi.org/10.1016/j.matpr.2020.12.1020

Engstrom, R., Carlsson-Kanyama, A. (2004) Food losses in food service institutions: Examples from Sweden. Food Policy, 29, 203-213. https://doi.org/10.1016/j.foodpol.2004.03.004

Gil-Soto, E., Armas-Cruz, Y., Morini-Marrero, S., RamosHenríquez, J.M. (2019). Hotel guests' perceptions of environmentally friendly practices in social media. International Journal of Hospitality Management, 78, 59-67. https://doi.org/10.1016/j. ijhm.2018.11.016

Gössling, S., Hall, C.M., Scott, D. (2015). Tourism and water. Bristol: Channel View Publications. https://doi. org/10.21832/9781845415006

Graci, S., Dodds, R. (2008). Why go green? The business case for environmental commitment in the Canadian hotel industry. Anatolia: An International Journal of Tourism and Hospitality Research, 19 (2), 251-270. https://doi.org/10.1080/13032917.2 008.9687072

Green Hotel Association (2015). What are green hotels? Retrieved from: http://greenhotel.com/index.php (20.03.2021).

Gupta, A., Satyabhusan, D., Mishra, A. (2019). All that glitters is not green: Creating trustworthy ecofriendly services at green hotel. Tourism Management, 70, 155-169. https://doi. org/10.1016/j.tourman.2018.08.015

Hebák, P., Hustopecký, J., Pecáková, I., Průša, M., Řezánková, H., Svobodová, A., Vlach, P. (2007). Multidimensional statistical methods 3. Prague: Informatorium.

Hou, H., Wu, H. (2021). Tourists' perceptions of green building design and their intention of staying in green hotels. Tourism and Hospitality Research, 21 (1), 115-128. https://doi. org/10.1177/1467358420963379

Juvan, E., Grün, B., Zabukovec Baruca, P., Dolnicar, S. (2021). Drivers of plate waste at buffets: A comprehensive conceptual model based on observational data and staff insights. Annals of Tourism Research Empirical Insights, 2, 100010. https://doi. org/10.1016/j.annale.2021.100010

Kalábová, M., Abrhám, J. (2016). Hunting tourism as a sector with great potential for the development of Czech regions. In: V. Klímová, V. Žitek (eds), Proceedings of the 19th International Colloquium on Regional Sciences (pp. 1073-1079). Brno: Masaryk University. 
Kapera, I. (2018). Sustainable development in the hotel industry: Between theory and practice in Poland. Turyzm/Tourism, 28 (2), 23-30. https://doi.org/10.2478/tour-2018-0011

Kapera, I., Wszendybył-Skulska, E. (2017). Pro-ecological hotel policies as assessed by guests. Turyzm/Tourism, 27 (2), 57-62. https://doi.org/10.1515/tour-2017-0013

Khatter, A., White, L., Pyke, J., McGrath, M. (2021). Stakeholders' influence on environmental sustainability in the Australian hotel industry. Sustainability, 13, 1351. https://doi.org/10.3390/ su13031351

Moise, M.S., Gil-Saura, I., Molina, M.E.R. (2021). The importance of green practices for hotel guests: Does gender matter? Economic Research-Ekonomska Istraživanja, 34, 1-22. https://doi. org/10.1080/1331677X.2021.1875863

Omune, B., Kambona, O., Wadongo, B., Wekesa, A. (2021). Environmental management practices implemented by the hotel sector in Kenya. World Leisure Journal, 63 (1), 98-108. https://doi.org/10.1080/16078055.2021.1888001

Patúš, P., Gúčik, M. (2005). Manažment ubytovacej prevádzky hotela. Banská Bystrica: Slovensko-švajčiarske združenie pre rozvoj cestovného ruchu.

Petkova, E. (2017). Environmental practices of hotel businesses. In: M. Assenova (ed.), Proceedings of the international scientific conference on contemporary tourism - traditions and innovations (pp. 94-108). Sofia: Sofia University St. Kliment Ohridski.

Pirani, S.I., Arafat, H.A. (2016). Reduction of food waste generation in the hospitality industry. Journal of Cleaner Production, 132, 129-145. https://doi.org/10.1016/j.jclepro.2015.07.146

Pizam, A. (2009). Green hotel: A fad, ploy or fact of life? International Journal of Hospitality Management, 28 (1), 1. https:// doi.org/10.1016/j.ijhm.2008.09.001

Priefer, C., Jörissen, J., Bräutigam, K.R. (2016). Food waste prevention in Europe: A cause-driven approach to identify the most relevant leverage points for action. Resources, Conservation, and Recycling, 109, 155-165. https://doi.org/10.1016/j. resconrec.2016.03.004

Ratinger, T., Vančurová, I., Hebáková, L., Pilecká, J., Bošková, I., Kormaňáková, M., Strejcová, A. (2020). Jak šetřit jídlem? Přiručka redukce plýtvání potravinami ve veřejném stravování. Praha: TAČR.

Rawashdeh, A.A., Al-Ababneh, M.M. (2021). Hotel guests' perceptions of environmentally friendly practices in Jordan. Journal of Environmental Management and Tourism, 12 (1), 107120. https://doi.org/10.14505/jemt.v12.1(49).09

Reddy, M.V., Wilkes, K. (2015). Tourism in the green economy. New York, NY: Routledge Taylor \& Francis Group. https:/ doi.org/10.4324/9781315885681

Sadom, N.Z.B.M., Quoquab, F., Mohammad, J. (2021). 'Waste not, want not': Fostering frugality amongst Muslim tourists in the Malaysian hotel industry. Journal of Islamic Marketing, ahead-of-print.

Sangeetha, R. (2020). Environmental sustainability practices for hotel in Chennai. Malaya Journal of Matematik, 8 (2), 1740-1745.

Sangeetha, R., Rebecca, J. (2020). What makes more positive thinking and implementation towards green and environment sustainable practices: An observation among selected star hotels from Chennai using multiple regression model. Malaya Journal of Matematik, 8 (2), 1482-1485.

Soria, E.L., Parra, D.P. (2021). Environmental approach in the hotel industry. Riding the wave of change. Sustainable Futures, 3, 100050. https://doi.org/10.1016/j.sftr.2021.100050

Švec, R., Martinát, S., Pícha, K., Klusáček, P., Knotek, J., Schaefer, J.C., Navrátil, J. (2021). What drives visitors to tourist sites to choose 'green' hotel facilities? Environment, Development and Sustainability, ahead-of-print. https://doi.org/10.1007/ s10668-021-01286-3

Tiwari, S., Dambhare, A., Tripathi, R. (2020). Eco-friendly practices in star category hotel of Lucknow: An exploratory study. AVAHAN: A Journal on Hospitality and Tourism, 8 (1), 9-16.

Tourkolias, C., Kontogianni, A., Damigos, D., Skourtos, M. (2020). Exploring the factors influencing energy efficiency in the Greek hotel sector. Acta Innovations, 37 (5), 5-20. https://doi. org/10.32933/ActaInnovations.37.1

Tran, B. (2009). Green management: The reality of being green in business. Journal of Economics, Finance and Administrative Science, 14 (27), 21-45. https://doi.org/10.46631/jefas.2009. $\mathrm{v} 14 \mathrm{n} 27.02$

Trejos, N. (2013). Green of the road: Airlines, hotel, cars more eco-friendly. USA TODAY. Retrieved from: https://www. pressreader.com (9.04.2021).

Wan, Y.K.P., Chan, S.H.J., Huang, H.L.W. (2017). Environmental awareness, initiatives and performance in the hotel industry of Macau. Tourism Review, 72 (1), 87-103. https://doi.org/10.1108/ TR-06-2016-0016

Yoon, H., Sauri, D., Rico, A. (2021). The water-energy nexus in hotel and recreational activities of a mass tourism resort: The case of Benidorm. Current Issues in Tourism, 24. https://doi. org/10.1080/13683500.2021.1893283

Zámková, M., Prokop, M. (2014). Comparison of consumer behavior of Slovaks and Czechs in the market of organic products by using correspondence analysis. Acta Universitatis Agriculturae et Silviculturae Mendelianae Brunensis, 62 (4), 783-795. https://doi.org/10.11118/actaun201462040783

Zuraikat, F.M., Roe, L.S., Smethers, A.D., Rolls, B.J. (2018). Doggy bags and downsizing: Packaging uneaten food to go after a meal attenuates the portion size effect in women. Appetite, 129, 162-170. https://doi.org/10.1016/j.appet.2018.07.009 